\title{
Tanggung Gugat Ahli Waris Notaris terhadap Pewaris yang Dijatuhi Hukuman Ganti Rugi
}

\author{
Andi Fitra \\ Vniversitas Narotama Surabaya|19fitra@gmail.com \\ Ghansham Anand
}

Universitas $\mathcal{N a r o t a m a}$ Surabaya

\begin{abstract}
Authentic deeds in agreements made by notaries do not rule out the possibility to bring up legal matters and cause lawsuit case from the parties in the deed. The limitation of accountability of notaries can be required as long as they are still authorized to perform the duties of a notary. However, if the notary has passed away in the making of the deed, it becomes a legal matter and has harmed the parties. then what happens in interpretations of positive law is the one that must bear the punishment for damages made by the notary, based on a decision that has the legal binding verdict (inkracht) is the heir of the notary.
\end{abstract}

\begin{abstract}
Abstrak: Akta otentik dalam perjanjian yang dibuat oleh Notaris tidak menutup kemungkinan menimbulkan masalah hukum dan memunculkan suatu perkara gugatan yang berasal dari para pihak yang berada dalam akta. Batasan tanggung gugat notaris tersebut dapat diminta sepanjang mereka masih berwenang dalam melaksanakan tugas jabatan sebagai notaris. Namun apabila notaris tersebut telah meninggal dunia dalam pembuatan akta semasa hidupnya yang menjadi suatu permasalahan hukum dan telah merugikan para pihak, maka yang terjadi dalam penafsiran-penafsiran hukum sekarang adalah yang harus menanggung hukuman ganti rugi atas kesalahan yang dilakukan oleh notaris tersebut berdasarkan putusan yang mempunyai kekuatan hukum tetap adalah ahli waris dari notaris tersebut tersebut.
\end{abstract}

Kata Kunci: Tanggung gugat, notaris, ahli waris

\section{A. Pendahuluan}

Hukum Indonesia saat ini seiring perjalanan waktu terus melakukan adaptasi terhadap pengaruh perkembangan 
yang terjadi baik itu di dalam negeri maupun pengaruh dari luar, sehingga nantinya Pemerintah dalam melaksanakan penyelenggaraan negara dalam menjalankan suatu kebijakan pemerintahan dapat terkontrol dan sesuai dengan peraturan perundang-undangan tersebut.

Indonesia yang mengikuti perkembangan zaman khususnya di bidang perjanjian dan kerjasama saat ini, dibutuhkan suatu perjanjian yang tertulis sehingga memiliki bukti, di sinilah terdapat regulasi yang mengatur notaris. Kehadiran notaris sangat dinantikan untuk memberikan jaminan kepastian atas transaksi bisnis yang dilakukan para pihak. Sifat otentik atas akta yang dibuat oleh notaris merupakan wujud kepastian hukum bagi para pihak yang bertransaksi.

Notaris sebagai salah satu profesi di bidang hukum bertugas memberikan pelayanan hukum serta menciptakan kepastian, ketertiban dan perlindungan hukum dalam masyarakat. Dalam rangka melaksanakan tugas tersebut notaris mengemban tanggung jawab yang berkenaan dengan alat bukti yang dapat menentukan dengan jelas hak dan kewajiban seseorang sebagai subjek hukum dalam masyarakat.

Undang-Undang Nomor 2 Tahun 2014 tentang perubahan atas Undang-Undang Nomor 30 tahun 2004 tentang jabatan Notaris (UUJN Perubahan), yang saat ini merupakan peraturan pelaksana dari ketentuan pasal BW berisikan pengaturan umum tentang notaris sebagai pejabat umum yang berwenang membuat akta Otentik. Berdasarkan pengertian mengenai Notaris serta tugas dan kewenangannya itu apabila di kaitkan dengan Pasal 15 ayat (1) UUJN Perubahan maka teranglah bahwa notaris mempunyai peranan yang sangat penting dalam setiap hubungan hukum dalam kehidupan masyarakat.

Notaris sebagai pejabat umum pada dasarnya mempunyai kewenangan utama yaitu pembuatan akta otentik dan kewenangan lainnya yang ditentukan oleh peraturan 
perundang-undangan. Pembuatan akta otentik oleh notaris dapat karena diharuskan oleh peraturan perundangundangan dan/atau pembuatan akta otentik yang tidak di haruskan oleh peraturan perudang-undangan namun dikehendaki oleh para pihak, sepanjang tidak ditugaskan atau dikecualikan kepada pejabat lain atau orang lain. ${ }^{1}$

Keterlibatan notaris dalam pembuatan akta otentik yang diharuskan oleh peraturan perundang-undangan umumnya di berlakukan terhadap hal-hal substansial. Dalam hal ini akta notaris merupakan syarat adanya suatu perbuatan hukum tertentu, sehingga dengan tidak adanya atau tidak di buatnya akta tersebut perbuatan hukum itu tidak terjadi. ${ }^{2}$

Akta otentik dalam perjanjian yang dibuat oleh Notaris untuk kepentingan para pihak, tidak menutup kemungkinan menimbulkan masalah hukum. Masalah hukum ini bisa saja muncul pada saat waktu yang sangat lama dimana terjadinya suatu perkara gugatan antara para pihak yang berada dalam akta yang dibuat oleh notaris itu. Akibat dari perkara para pihak yang ada dalam akta notaris seringkali dalam suatu pemeriksaan, notaris juga dikaitkan oleh karena sebagai pelaksana yang menuangkan isi dari perjanjian para pihak yang berseteru.

Dalam suatu permasalahan hukum yang timbul akibat dibuatnya suatu akta oleh notaris saat menjalankan tugas dan jabatannya di bidang kenotariatan, kedudukan Notaris sebagai pelaksana hukum, sedangkan pada waktu Notaris dikenakan tanggung gugat, kedudukan Notaris sebagai yang dikenakan hukum, berhadapan dengan penerapan sanksi. Apabila seorang Notaris, sudah tidak menjabat lagi meskipun yang bersangkutan masih hidup tidak dapat di mintakan lagi tanggung gugat dalam bentuk apapun dan Notaris penyimpan

1 Sjaifurrachman dan Habib Adjie, Aspek Pertanggungjawaban Notaris dalam Pembuatanb Akta, (Bandung: Mandar Maju, 2011), h. 121.

2 Teguh Samudera, Hukum Pembuktian dalam Acara Perdata, (Bandung: Alumni, 1992), h. 46.

Al-Qānūn, Vol. 20, No. 2, Desember 2017 
protokol wajib memperlihatkan atau menyerahkan grosse/akta, salinan akta atau kutipan akta atau oleh Majelis Pengawas Daerah untuk protokol Notaris yang telah berumur dua puluh lima tahun atau lebih, Pasal 63 ayat (5) UUJN Perubahan. Batasan tanggung gugat notaris, dapat diminta sepanjang mereka masih berwenang dalam melakanakan tugas jabatan sebagai notaris atau kesalahan-kesalahan yang di lakukan dalam menjalankan tugas jabatan sebagai notaris dan sanksi-sanksi yang dapat dikenakan terhadap notaris dapat dijatuhkan sepanjang notaris masih berwenang untuk melaksanakan tugas jabatan sebagai notaris, dengan kontruksi tanggung gugat seperti tersebut di atas, tidak akan ada lagi notaris setelah yang bersangkutan berhenti dari tugasnya sebagai notaris.

Berdasarkan penjelasan tersebut jelas bahwa notaris, batasan tanggung gugat apabila masih menjabat namun yang terjadi dalam penafsiran-penafsiran hukum bahwa akta yang dibuat oleh notaris yang dijadikan suatu permasalahan hukum yang merugikan para pihak, sehingga sampai dimana tanggung gugat notaris tersebut, dan apabila telah meninggal dunia maka Notaris yang membuat akta tersebut berdasarkan putusan yang mempunyai kekuatan hukum tetap, maka yang harus menanggung hukuman ganti rugi atas kesalahan yang dilakukan oleh notaris itu adalah ahli waris dari notaris tersebut, oleh karena itu dari uraian tersebut di atas, maka penulis ingin meneliti lebih lanjut mengenai permasalahan tersebut.

\section{B. Bentuk Tanggung Gugat Notaris atas Kesalahan dalam Akta yang dibuatnya}

Tuntutan tanggung jawab oleh Notaris muncul sejak terjadinya sengketa berkaitan dengan akta yang telah dibuat dengan memenuhi unsur-unsur dalam perbuatan melawan hukum meliputi perbuatan manusia yang memenuhi rumusan peraturan perundang-undangan, artinya berlaku asas legalitas, nulum delictumnulla poena sine praevia lege 
poenali, dan perbuatan itu merupakan perbuatan melawan hukum. Konsep pertanggung jawaban ini apabila dikaitkan dengan profesi Notaris, maka Notaris dapat dipertanggung jawabkan atas kesalahan dan kelalaiannya dalam pelaksanaan tugas dan jabatannya. Secara umum pembatasan mengenai tanggunggugat dapat diminta sepanjang mereka masih berwenang dalam melakukan akan tugas jabatan sebagai Notaris atau kesalahan-kesalahan yang dilakukan dalam menjalankan tugas jabatan sebagai Notaris dan sanksisanksi yang dapat dikenakan terhadap Notaris dapat dijatuhkan sepanjang Notaris masih berwenang untuk melaksanakan tugas jabatan sebagai Notaris, dengan kontruksi tanggung gugat seperti tersebut di atas, tidak akan ada lagi Notaris, Notaris pengganti, Notaris pengganti khusus dan pejabat sementara Notaris dimintai tanggung gugat lagi setelah yang bersangkutan berhenti dari tugasnya sebagai Notaris. ${ }^{3}$ Berdasarkan penafsiran seperti itu, maka akta notaris sebagai akta otentik yang akan membuktikan dirinya sendiri sebagai alat bukti yang sah menurut hukum karena akta Notaris sebagai akta otentik harus dilihat dan dinilai apa adanya sehingga apabila ada pihak-pihak yang menuduh atau menilai, bahwa akta Notaris tersebut palsu atau tidak benar, maka pihak yang menuduh atau menilai tersebut harus dapat membuktikan tuduhan atau penilaian sendiri melalui proses hukum gugatan perdata bukan dengan cara mengadukan Notaris kepada pihak kepolisian. ${ }^{4}$ Akta otentik menjamin adanya kepastian hukum. Dengan demikian dapat dihindari kerugian maupun sengketa yang akan terjadi dikemudian hari. Dengan hubungan hukum seperti itu, maka perlu ditentukan kedudukan hubungan hukum tersebut yang merupakan awal dari tanggunggugat Notaris. ${ }^{5}$

3 Sjaifurrachman dan Habib Adjie, Aspek Pertanggungjawaban Notaris, h. 193.

${ }^{4}$ Ibid

5 Istilah "Tanggunggugat" dipergunakan terutama terhadap kesalahan-kesalahan yang dilakukan dalam menjalankan jabatan khusus 
Berkaitan dengan adanya kesalahan dalam akta yang dibuat oleh Notaris, Akta Berita Acara Pembetulan merupakan akta notaris yang termasuk dalam akta relas khusus (akta verbal khusus). Dikatakan sebagai akta relas khusus karena akta tersebut dapat dibuat oleh notaris atas inisiatifnya sendiri, tanpa harus ada permintaan dari para pihak yang berkepentingan. Jadi, apabila notaris mengetahui bahwa di dalam suatu minuta akta yang sudah ditandatangani terdapat kesalahan ketik, ia bisa dengan segera melakukan pembetulan terhadap kesalahan itu, meskipun tanpa bantuan atau persetujuan dari para penghadap, sepanjang pembetulan itu sesuai dengan kenyataan yang terjadi dan tidak melampaui kewenangan notaris.

Setelah Akta Berita Acara Pembetulan selesai dibuat, berdasarkan Pasal 51 ayat (2) UUJN, notaris wajib memberikan catatan tentang adanya pembetulan tersebut pada minuta akta asli dengan menyebutkan tanggal dan nomor Akta Berita Acara Pembetulan. Yang dimaksud dengan "minuta akta asli" adalah minuta akta yang di dalamnya terdapat kesalahan tulis dan/atau kesalahan ketik. Selanjutnya, notaris menyampaikan salinan Akta Berita Acara Pembetulan tersebut kepada para pihak. ${ }^{6}$

Kewenangan yang dimaksud dalam Pasal 51 UUJN itu berlaku pula untuk minuta akta yang telah dikeluarkan salinannya.Adapun alasannya sebagai berikut.

1. Pasal 51 ayat (1) UUJN hanya menyebutkan frasa "minuta akta yang telah ditandatangani", tanpa memberikan perkecualian terhadap minuta akta yang telah dikeluarkan salinannya. Dengan demikian, kewenangan notaris untuk membetulkan kesalahan ketik tersebut berlaku bagi minuta akta yang telah ditandatangani, baik

tertentu (beroepsaansprakelijkheid). Lihat: Marthalena Pohan, Tanggunggugat Advocaat, Dokter, Notaris, (Surabaya: Bina Ilmu, 1985), h.11.

${ }^{6}$ Ibid

Al-Qānūn, Vol. 20, No. 2, Desember 2017 
yang salinannya belum dikeluarkan maupun sudah dikeluarkan.

2. Pasal 16 ayat (1) huruf c UUJN memberikan kewajiban kepada notaris untuk mengeluarkan salinan akta berdasarkan minuta akta. Menurut Pasal 1 angka 9 UUJN, salinan akta adalah salinan kata demi kata dari seluruh akta dan pada bagian bawah salinan akta tercantum frasa "diberikan sebagai salinan yang sama bunyinya". Berdasarkan kedua ketentuan tersebut, dapat disimpulkan bahwa walaupun di dalam suatu minuta akta yang telah ditandatangani terdapat kesalahan ketik, notaris wajib mengeluarkan salinan akta yang isinya sama persis dengan minutanya. Dengan demikian, tidak perlu dipermasalahkan salinan dikeluarkan sebelum atau setelah dibetulkannya kesalahan ketik, karena kapanpun salinan itu dikeluarkan isinya harus tetap sama dengan minuta akta.

3. Pasal 51 ayat (3) menentukan bahwa salinan Akta Berita Acara Pembetulan wajib disampaikan kepada para pihak. Sewajarnya salinan akta dari minuta akta yang di dalamnya terdapat kesalahan ketik telah disampaikan kepada para pihak sebelum atau setidak-tidaknya pada saat yang sama dengan penyampaian salinan Akta Berita Acara Pembetulan.

Untuk menafsirkan kesalahan-kesalahan pada akta yang dibuatnya yang seperti apa yang boleh dibetulkan dengan cara sebagaimana dimaksud dalam Pasal 51 UUJN, terlebih dahulu perlu diingat bahwa terdapat 2 (dua) jenis akta notaris, yaitu akta partai dan akta relas. Akta partai adalah akta yang "dibuat di hadapan" notaris, sedangkan akta relas adalah akta yang "dibuat oleh" notaris. Kedua jenis akta tersebut memiliki sifat yang berbeda. Oleh karena itu, penafsiran dan batasan penerapan cara pembetulan sebagaimana dimaksud dalam Pasal 51 UUJN tersebut juga bergantung pada jenis aktanya. Namun, perlu diingat bahwa perbaikan dengan cara tersebut hanya dapat dilakukan bila 
kesalahan ketik tidak mengubah substansi perjanjian. Apabila kesalahan ketik yang terletak pada isi perjanjian ternyata bersifat substantif dan salah satu pihak tidak mau hadir kembali di hadapan notaris, maka upaya terakhir yang dapat dilakukan oleh pihak yang dirugikan karena kesalahan pada akta yang dibuatnya itu adalah mengajukan gugatan ke pengadilan.

Selain itu apabila kesalahan-kesalahan pada akta yang dibuatnya pada suatu akta notaris terjadi karena notaris yang bersangkutan lalai dan tidak berhati-hati dalam menjalankan jabatannya. Oleh karena itu, notaris telah melanggar kewajibannya untuk bertindak secara saksama sebagaimana diwajibkan oleh Pasal 16 ayat (1) huruf a UUJN-P. sanksi merupakan tindakan hukuman untuk memaksa orang menepati perjanjian atau mentaati ketentuan undangundang. ${ }^{7}$ Berikut ketentuan Sanksi dalam pasal 16 Pasal (11), (12) dan (13) UUJN-P sebagai berikut:

1. Pasal 16 ayat (11) Notaris yang melanggar ketentuan sebagaimana dimaksud pada ayat (1) huruf a sampai dengan huruf 1 dapat dikenai sanksi berupa:

a. peringatan tertulis;

b. pemberhentian sementara;

c. pemberhentian dengan hormat; atau

d. pemberhentian dengan tidak hormat.

2. Pasal 16 ayat (12), Selain dikenai sanksi sebagaimana dimaksud pada ayat (11), pelanggaran terhadap ketentuan Pasal 16 ayat (1) huruf j dapat menjadi alasan bagi pihak yang menderita kerugian untuk menuntut penggantian biaya, ganti rugi, dan bunga kepada Notaris.

3. Pasal 16 ayat (13) Notaris yang melanggar ketentuan sebagaimana dimaksud pada ayat (1) huruf $n$ dapat dikenai sanksi berupa peringatan tertulis.

7 Departemen Pendidikan Nasional, Kamus Besar Bahasa Indonesia Pusat Bahasa (Edisi Keempat), (Jakarta: Gramedia Pustaka Utama, 2008), h. 1224 . 
Sebuah akta dikatakan cacat hukum apabila dalam akta tersebut terdapat cacat dalam kehendak terjadi karena adanya paksaan, kekeliruan, tipuan, dan penyalahgunaan keadaan. Dalam hal batal demi Hukum, merupakan istilah yang digunakan untuk menilai suatu perjanjian jika tidak memenuhi syarat obyektif, yaitu suatu hal tertentu, dan sebab yang tidak dilarang serta istilah dapat dibatalkan jika suatu perjanjian tidak memenuhi syarat subjektif yaitu sepakat mereka yang mengikatkan dirinya dan kecakapan untuk membuat suatu perikatan. Berdasarkan pasal 84 UU No. 30 Tahun 2004 tentang Jabatan Notaris, Para Pihak yang memiliki kepentingan terhadap akta tersebut dapat menuntut biaya kerugian berikut bunga kepada notaris yang telah melakukan kelalaian tersebut.

Berkaitan dengan adanya akta yang cacat hukum tersebut maka Notaris sebagai pejabat yang membuat akta tersebut apabila dapat dibuktikan terdapat unsur kesalahan yang diperbuat olehnya maka Notaris dapat bertanggung jawab dan bertanggung gugat. ${ }^{8}$ Dengan demikian apabila ada Perbuatan Melanggar Hukum yang dilakukan oleh Notaris yang mengakibatkan akta tersebut batal demi hukum atau dibatalkan maka Notaris tersebut dapat dihukum bertanggung gugat dengan mengganti kerugian, biaya dan bunga kepada pihak yang dirugikan. Apabila dalam perbuatan notaris membuat akta tersebut dapat dibuktikan terdapar unsur pidana maka Notaris dapat diberikan sanksi pidana sebagai bentuk tanggung jawab dalam ranah pidana.

\section{Kedudukan Hukum Ahli Waris Almarhum Notaris Apabila Terdapat Tuntutan dari Pihak yang Dirugikan Akibat Akta yang Dibuat Almarhum Notaris \\ Warisan adalah kekayaan yang berupa kompleks} aktiva dan pasiva si pewaris yang berpindah kepada para ahli

8 J.H. Nieuwenhuis, Hoofdstukken Verbintenissenrecht, terjemahan, (Surabaya: Universitas Airlangga, 1985), h. 135.

Al-Qānūn, Vol. 20, No. 2, Desember 2017 
waris. ${ }^{9}$ Menurut Eman Suparman wujud harta peninggalan menurut hukum perdata Barat yang tercantum dalam KUH Perdata (BW) meliputi "seluruh hak dan kewajiban dalam lapangan hukum harta kekayaan yang dapat dinilai dengan uang" sehingga harta peninggalan yang akan diwarisi oleh para ahli waris tidak hanya meliputi hal-hal yang bermanfaat berupa aktiva atau keuntungan, melainkan juga termasuk hutang-hutang si pewaris yang merupakan pasiva dari harta kekayaan yang ditinggalkan sehingga "kewajiban membayar hutang pada hakekatnya beralih juga kepada ahli waris"10 Hal tersebut diatur dalam Pasal 1100 BW yang menyebutkan "Para waris yang telah menerima suatu warisan diwajibkan dalam hal pembayaran utang, hibah wasiat dan lain-lain beban, memikul bagian yang seimbang dengan apa yang diterima masing-masing dan warisan".

Dalam hukum waris perdata berlaku asas-asas yaitu: ${ }^{11}$

1. Hanyalah hak-hak dan kewajiban dalam lapangan hukum kekayaan harta benda saja yang dapat diwariskan.

2. Adanya Saisine bagi ahli waris, yaitu : sekalian ahli waris dengan sendirinya secara otomatis karena hukum memperoleh hak milik atas segala barang, dan segala hak serta segala kewajiban dari seorang yang meninggal dunia.

3. Asas Kematian, yaitu ; Pewarisan hanya karena kematian.

4. Asas Individual, yaitu : Ahli waris adalah perorangan (secara pribadi) bukan kelompok ahli waris.

5. Asas Bilateral, yaitu : Seseorang mewaris dari pihak bapak dan juga dari pihak ibu.

${ }^{9}$ J. Satrio, Hukum Waris, (Bandung: Alumni, 1992), h.8

10 Eman Suparman, Hukum Waris di Indonesia dalam Perspektif Islam, Adat, dan BW, (Bandung: Refika Aditama, 2005), h. 25.

11 M. Idris Ramulyo, Perbandingan Hukum Kewarisan Islam dengan Kewarisan Kitab Undang-undang Hukum Perdata, (Jakarta: Sinar Grafika, 2004), h. 95-96 
6. Asas Penderajatan, yaitu : Ahli waris yang derajatnya dekat dengan pewaris menutup ahli waris yang lebih jauh derajatnya.

Untuk terjadinya pewarisan, diperlukan adanya unsurunsur sebagai berikut : ${ }^{12}$

1. Adanya orang yang meninggal dunia (erflater) yaitu orang yang meniggalkan harta warisan dan disebut Pewaris.

2. Adanya orang yang masih hidup (erfgenaam) yaitu orang yang menurut undang-undang atau testamen berhak mendapatkan warisan dari orang yang meninggal dunia mereka disebut Ahli Waris.

3. Adanya benda yang di tinggalkan (erftenis, nalatenschap) yaitu sesuatu yang di tinggalkan oleh pewaris pada saat ia meninggal dunia, yang disebut harta warisan, wujud harta warisan inibisa berbentik Activa (piutang, tagihan) atau Pasiva (hutang).

Syarat-syarat Terjadinya Pewarisan Untuk memperoleh warisan, haruslah dipenuhi syarat-syarat yaitu:

1. Syarat yang berhubungan dengan pewaris Untuk terjadinya pewarisan maka si pewaris harus sudah meninggal dunia/mati, sebagaimana yang disebutkan dalam Pasal 830 KUH Perdata. Matinya pewaris dalam hal ini dapat dibedakan menjadi:

a. Matinya pewaris diketahui secara sungguh-sungguh (mati hakiki), yaitu dapat dibuktikan dengan panca indra bahwa ia benar-benar telah mati.

b. Mati demi hukum, dinyatakan oleh Pengadilan, yaitu : tidak diketahui secara sungguh-sungguh menurut kenyataan yang dapat dibuktikan bahwa ia sudah mati.

2. Syarat yang berhubungan dengan ahli waris Orang-orang yang berhak/ahli waris atas harta peninggalan harus sudah ada atau masih hidup saat kematian si pewaris. Hidupnya ahli waris dimungkinkan dengan :

12 A. Wahab Afif, Fiqh Mewaris, (Semarang: Yayasan Ulumul Quran, 1994), h. 53.

Al-Qānūn, Vol. 20, No. 2, Desember 2017 
a. Hidup secara nyata, yaitu dia menurut kenyataan memang benar-benar masih hidup, dapat dibuktikan dengan panca indra.

b. Hidup secara hukum, yaitu dia tidak diketahui secara kenyataan masih hidup. Dalam hal ini termasuk juga bayi dalam kandungan ibunya (Pasal 1 ayat 2 KUH Perdata).

Dalam BW terdapat dua cara untuk mendapat suatu warisan, yaitu: 1) Secara $a b$ intestato yaitu suatu bentuk pewarisan dimana hubungan darah merupakan faktor penentu dalam hubungan pewarisan antara pewaris dan ahli waris dan 2) secara testamentair (ahli waris karena ditunjuk dalam surat wasiat). Selanjutnya Terdapatnya sebab-sebab menurut Undang-undang ahli waris tidak patut atau terlarang (onwaardig) untuk menerima warisan dari si pewaris yaitu: ${ }^{13}$

1. Ahli waris menurut undang-undang yang dinyatakan tidak patut untuk menerima warisan, dalam Pasal 838 KUH Perdata, adalah:

a. Mereka yang telah dihukum karena dipersalahkan telah membunuh atau mencoba membunuh si pewaris.

b. Mereka yang dengan putusan hakim pernah dipersalahkan karena secara fitnah telah melakukan pengaduan terhadap si pewaris, ialah suatu pengaduan telah melakukan kegiatan kejahatan yang diancam hukuman penjara lima tahun lamanya atau lebih berat.

c. Mereka yang dengan kekerasan atau perbuatan telah mencegah si pewaris untuk membuat atau mencabut surat wasiat.

d. Mereka yang telah menggelapkan, merusak atau memalsukan surat wasiat si pewaris.

2. Ahli waris menurut wasiat yang dinyatakan tidak patut untuk menerima warisan dalam Pasal 912 KUH Perdata, adalah :

13 Suparman Usman, Ikhtisar Hukum Waris Menurut Kitab Undangundang Hukum Perdata (Burgerlijk Wetboek), (Serang: Darul Ulum Press. 1993 ), h. 58.

Al-Qānūn, Vol. 20, No. 2, Desember 2017 
a. Mereka yang telah dihukum karena membunuh si pewaris.

b. Mereka yang telah menggelapkan, membinasakan atau memalsukan surat wasiat si pewaris.

c. Mereka yang dengan paksaan atau kekerasan telah mencegah si pewaris untuk mencabut atau mengubah surat wasiatnya.

Ahli waris adalah anggota keluarga orang yang meninggal dunia yang menggantikan kedudukan pewaris dalam bidang hukum kekayaan karena meninggalnya pewaris. ${ }^{14}$ Menurut Abdulkadir Muhammad ahli waris adalah setiap orang yang berhak atas harta peninggalan pewaris dan berkewajiban menyelesaikan hutang-hutangnya. ${ }^{15}$ Hak dan kewajiban tersebut timbul setelah pewaris meninggal dunia. Adapun Hak dan Kewajiban Pewaris dan Ahli Waris adalah sebagai berikut: 16

1. Pewaris

Pewaris dalam hal waris berhak memberikan testament (wasiat) namun disisi lain juga berkewajiban untuk memperhatikan legitieme portie.

2. Ahli Waris

Ahli waris mempunyai hak diantaranya:

a. Menentukan sikap terhadap harta peninggalan

b. Menerima baik secara diam-diam ataupun secara tegas

c. Menerima dengan catatan (beneficiare)

d. Menolak warisan

Ahli waris mempunyai kewajiban diantaranya:

a. Memelihara Harta Peninggalan

b. Membagi warisan berdasarkan ketentuan hukum waris B.W.

14 Surini Ahlan Sjarif dan Nurul Elmiyah, Hukum Kewarisan Perdata Barat, (Jakarta: Fakultas Hukum Universitas Indonesia, 2005), h. 11.

15 Abdulkadir Muhammad, Hukum Perdata Indonesia, (Bandung: Citra Aditya Bakti, 2000), h. 282.

16 Henny Tanuwidjaja, Hukum Waris Menurut BW, (Bandung: Refika Aditama, 2012), h. 5. 
c. Melunasi hutang pewaris jika ada

d. Melaksanakan wasiat

Ahli waris adalah orang-orang yang berhak atas harta peninggalan orang yang meninggal dunia. Tetapi tidak seluruh ahli waris yang ada selalu menerima harta peninggalan, sebab para ahli waris yang lebih dekat kepada pewaris, menutup yang lebih jauh berdasarkan urutan. ${ }^{17}$

Jika terbuka suatu warisan, seorang ahli waris dapat memilih apakah ia akan menerima atau menolak warisan itu, atau ada pula kemungkinan untuk menerima tetapi dengan ketentuan ia tidak akan diwajibkan membayar hutang-hutang si meninggal, yang melebihi bagiannya dalam warisan itu. BW memberikan tiga macam sikap yang harus dipilih salah satunya oleh ahli waris yaitu: ${ }^{18}$

a. Menerima seluruh harta warisan, yang dalam pengertian ini berarti juga meliputi utang-utang si peninggal warisan

b. Menerima dengan syarat bahwa harus diperinci barang-barangnya dengan pengertian bahwa utangutangnya dapat dibayar sekedar harta warisan mencukupi.

c. Menolak harta warisan dengan pengertian bahwa ia tidak tahu menahu tentang pengurusan harta warisan tersebut.

Apabila ahli waris mengambil sikap pertama, menurut pasal $1048 \mathrm{BW}$ dapat dilakukan dengan tegas atau secara diam-diam. Pasal 1048 BW menyatakan "Penerimaan suatu warisan dapat dilakukan secara tegas atau dengan diam-diam; terjadilah dengan tegas penerimaan itu jika seorang didalam suatu tulisan otentik atau suatu tulisan di

17 Ridwan Setiawan dalam Oemar Moecthar, "Kedudukan Negara sebagai Pengelola Warisan atas Harta Peninggalan Tak Terurus dalam Sistem Hukum Waris Burgerlijk Wetboek", Yuridika, Vol. 32, 2 Mei 2017, h. 284.

18 Ibid., h.61

Al-Qānūn, Vol. 20, No. 2, Desember 2017 
bawah tangan menamakan dirinya waris atau mengambil kedudukan sebagai demikian; dengan diam-diam terjadilah penerimaan itu, jika seorang waris melakukan suatu perbuatan, yang dengan jelas menunjukkan maksudnya untuk menerima warisan tersebut, dan yang memang hanya dapat dilakukannya dalam kedudukannya sebagai waris". Berdasarakan pengertian tersebut maka penerimaan secara tegas adalah jika seorang ahli waris menerima kedudukannya sebagai ahli waris dengan menyatakannya dalam akta otentik ataupun akta dibawah tangan. Secara diam-dam dapat dimerngerti jika seorang ahli waris melakukan suatu perbuatan, misalnya mengambil atau menjual barang-barang warisan atau melunasi hutang-hutang si meninggal, dapat dianggap telah menerima warisan itu secara penuh. Namun apabila perbuatan ahli waris berhubungan dengan penguburan mayat dan tindakan melindungi/mengawasi warisan seperti menyimpan harta waris untuk sementara waktu maka berdasarkan pasal 1049 BW bukanlah sikap menerima warisan.

Apabila ahli waris memilih sikap kedua yaitu menerima dengan syarat maka harta pribadi ahli waris tidak bercampur dengan harta warisan, dengan demikian utang-utang si peninggal warisan tidak akan dilunasi secara pribadi oleh ahli waris tersebut. Sikap penerimaan dengan syarat ini disebut juga "voorrecht van boedelbeschrijving" atau "beneficiaire aanvaarding." Ahli waris yang hendak memilih sikap kedua ini ini harus menyatakan kehendaknya kepada Panitera Pengadilan Negeri setempat di mana warisan itu telah terbuka. Akibat yang terpenting dari "beneficiaire aanvaarding", bahwa kewajiban si waris untuk melunasi hutang-hutang dan beban-beban lainnya dibatasi sedemikian rupa, sehingga pelunasan itu hanyalah dilakukan menurut kekuatan warisan, sehingga si waris tidak usah menanggung pembayaran hutang-hutang dengan 
kekayaannya sendiri. ${ }^{19}$ Adapun atas hal tersebut ahli waris yang memilih sikap menerima dengan syarat (beneficiary aanvarding) tersebut dibebani kewajiban diantaranya :20

a. Melakukan pencatatan adanya harta peninggalan dalam waktu empat bulan setelahnya ia menyatakan kehendaknya kepada Panitera Pengadilan Negeri, bahwa ia menerima warisannya secara beneficiair.

b. Mengurus harta peninggalan sebaik-baiknya.

c. Selekas-lekasnya membereskan urusan warisan ( $d e^{\prime}$ boedel tot effenheid brengen").

d. Apabila diminta oleh semua orang berpiutang harus memberikan tanggungan untuk harga benda-benda yang bergerak beserta benda-benda yang tak bergerak yang tidak diserahkan kepada orang-orang berpiutang yang memegang hypotheek.

e. Memberikan pertanggunganjawab kepada sekalian penagih hutang dan orang-orang yang menerima pemberian secara legaat. Pekerjaan ini berupa menghitung harga serta pendapatan-pendapatan yang mungkin akan diperoleh, jika barang-barang warisan dijual dan sampai berapa persen piutang-piutang dan legaten itu dapat dipenuhi.

f. Memanggil orang-orang berpiutang yang tidak terkenal, dalam surat kabar resmi. Sebenarnya, peraturan yang diberikan oleh undang-undang mengenai pemberesan harta peninggalan dalam hal penerimaan warisan secara beneficiair ini, adalah sangat sederhana dan kurang jelas.

Sikap terakhir yang dapat dipilih oleh ahli waris adalah menolak harta warisan. Sikap ini diatur dalam pasal 1057 BW yaitu "Menolak suatu warisan harus terjadi dengan

19 Hartono Soerjopratiknyo, Hukum Waris Tanpa Wasiat, (Yogyakarta: Andi Offset, 1983), h. 68.

20 Subekti, Pokok-pokok Hukum Perdata, (Jakarta: PT Intermasa, 1980), h. 104. 
tegas, dan harus dilakukan dengan suatu pernyataan yang dibuat dikepaniteraan Pengadilan Negeri, yang dlam daerah hukumnya terbuka warisan itu." Selanjutnya dalam pasal 1058 BW disebutkan ahli waris yang menolak warisannya dianggap tidak pernah telah menjadi waris.

Atas ketiga sikap tersebut, baik penerimaan maupun penolakan selalu dihitung berlaku surut sejak hari meninggalnya orang yang meninggalkan warisan. ${ }^{21}$ Sikap manapun yang diambil oleh ahli waris akan mempunyai pengaruh terhadap harta warisnya maupun terhadap dirinya, oleh karena itu oleh BW diberikan waktu dan hak untuk berpikir terlebih dahulu sebelum mengambil sikap (beraad). Mengenai hak untuk berpikir (recht van beraad) diatur dalam pasal 1023 BW sampai dengan pasal 1029 BW. Untuk berpikir ini maka ahli waris haruslah menyampaikan keterangan kepada Panitera Pengadilan Negeri agar dimasukkan dalam daftar dan tenggang waktu untuk berpikir ini menurut pasal 1024 BW ditetapkan selama 4 bulan dihitung sejak menyampaikan keterangannya kepada Panitera Pengadilan Negeri. ${ }^{22}$ Selama masa berpikir ini maka ahli waris diwajibkan untuk memelihara harta warisan (al seen good huisvader) dan jika terdapat barang-barang yang tidak dapat disimpan maka ahli waris dapat melaporkan kepada Ketua Pengadilan Negeri agar diambil tindakan penyelamatan.

Berdadarkan hal tersebut maka ahli waris pada dasarnya mempunyai hak waris saat si peninggal harta waris meninggal dunia dimana tidak hanya harta benda dan hak saja yang beralih kepada ahli waris melainkan juga kewajiban dan utang si peninggal harta waris. Namun para ahli waris oleh hukum diberikan pilihan untuk menentukan sikap atas hak waris tersebut karena

21 Ibid., h. 103.

${ }^{22}$ Henny Tanuwidjaja, Hukum Waris Menurut BW, h. 61-62.

Al-Qānūn, Vol. 20, No. 2, Desember 2017 
pada prinsipnya segala sesuatu yang ditinggalkan oleh orang yang meninggal dinyatakan sebagai peninggalan atau warisan. Termasuk di dalamnya bersangkutan dengan utang piutang, baik utang piutang itu berkaitan dengan pokok hartanya (seperti harta yang berstatus gadai), atau utang piutang yang berkaitan dengan kewajiban pribadi yang mesti ditunaikan (misalnya pembayaran kredit), juga di dalamnya terdapat harta yang akan diturunkan kepada para ahli waris yang sah

\section{Kewajiban Pembayaran Ganti Rugi Berdasarkan Putusan Pengadilan Merupakan Utang}

Sebagaimana telah diterangkan sebelumnya bahwa harta waris tidak hanya meliputi hak dan harta kekayaan milik si peninggal waris saja melainkan juga termasuk pula utang-utang yang harus dibayar oleh si peninggal warisan. Ter Haar Bzn menyatakan bahwa kewajiban-kewajiban untuk membayar hutang yang ada atau yang timbul pada waktu matinya atau karena matinya si peninggal warisan itu akhimya termasuk juga bagian-bagian daripada harta peninggalan walaupun sebagai bagian negatif. ${ }^{23}$ Dalam pasal 1100 BW disebutkan "Para waris yang menerima suatu warisan diwajibkan dalam hal pembayaran utang, hibah wasiat dan lain-lain beban, memikul bagian yang seimbang dengan apa yang diterima masing-masing dan warisan."

Utang berkaitan erat dengan perikatan bahkan Soedewi Masjchoen Sofwan menerjemahkan istilah hukum perikatan (verbitenissenrecht) itu dengan perutangan. Menurutnya perutangan itu merupakan hubungan hukum yang atas dasar itu seseorang dapat mengharapkan suatu prestasi dari seseorang yang lain jika perlu dengan

23 Ter Haar Bzn, Asas-asas dan Susunan Hukum Adat, Terj. K. Ng. Soebakti Poesponoto, (Jakarta: Pradnya Paramita, 1981), h. 252. 
perantaraan hakim. ${ }^{24}$ Menurut Yahya Harahap verbintennis mengandung pengertian "suatu hubungan hukum kekayaan/harta benda antara dua orang atau lebih, yang memberi kekuatan hak pada satu pihak untuk memperoleh prestasi dan sekaligus mewajibkan pada pihak lain untuk menunaikan prestasinya. ${ }^{25}$ Menurut Subekti yang dimaksud dengan perikatan oleh Buku III BW adalah:26 "Suatu hubungan hukum (mengenai harta benda) antara 2 orang, yang memberikan hak kepada satu untuk menuntut barang sesuatu dari yang lainnya, sedangkan orang lainnya ini diwajibkan memenuhi tuntutan itu. Buku II KUHPerdata mengatur perihal hubungan-hubungan hukum antara orang dengan benda (hak-hak perbendaan).

Buku III BW mengatur perihal hubungan-hubungan hukum antara orang dengan orang (hak-hak perseorangan), meskipun mungkin yang menjadi obyek juga suatu benda. Oleh karena sifat hukum yang termuat dalam Buku III BW itu selalu berupa suatu tuntut menuntut, maka isi Buku III BW ini juga dinamakan "hukum perutangan". Pihak yang berhak menuntut dinamakan pihak berpiutang atau kreditor, sedangkan pihak yang wajib memenuhi tuntutan dinamakan pihak yang berutang atau debitor. Adapun barang sesuatu yang dapat dituntut dinamakan prestasi yang menurut undang-undang dapat berupa:

1. Menyerahkan suatu barang

2. Melakukan suatu perbuatan

3. Tidak melakukan suatu perbuatan

Berdasarkan pengertian tersebut di atas maka utang adalah kewajiban yang melekat pada pihak yang berutang/debitor untuk memenuhi prestasi kepada pihak

24 Sri Soedewi Masjchoen Sofwan, Hukum Perdata (Hukum Perutangan): Bagian A, (Yogyakarta: Seksi Hukum Perdata UGM, 1980), h. 1.

25 Yahya Harahap, Segi-segi Hukum Perjanjian, (Bandung: Alumni, 1986), h.7

${ }^{26}$ Subekti, Pokok-pokok Hukum Perdata, h. 122-123.

Al-Qānūn, Vol. 20, No. 2, Desember 2017 
berpiutang atau kreditor. Dimana kewajiban tersebut dapat berupa menyerahkan sesuatu, melakukan sesuatu atau tidak melakukan sesuatu. Dalam hukum positif pengertian mengenai utang secara tegas dinyatakan dalam pasal 1 angka 6 Undang-Undang Nomor 37 Tahun 2004 tentang Kepailitan dan Penundaan Kewajiban Pembayaran Utang (UU Kepailitan dan PKPU) yaitu: "Utang adalah kewajiban yang dinyatakan atau dapat dinyatakan dalam jumlah uang baik dalam mata uang Indonesia maupun mata uang asing, baik secara langsung maupun yang akan timbul di kemudian hari atau kontinjen, yang timbul karena perjanjian atau undang-undang dan yang wajib dipenuhi oleh Debitor dan bila tidak dipenuhi memberi hak kepada Kreditor untuk mendapat pemenuhannya dari harta kekayaan Debitor."

Berdasarkan pengertian utang dalam UU Kepailitan dan PKPU tersebut maka sejalan dengan pendapat Soedewi Masjchoen Sofwan dan Subekti bahwa utang sangat identic dengan perikatan karena utang dan perikatan sama-sama dapat timbul karena perjanjian ataupun karena undangundang. Di dalam Pasal 1233 BW menyebutkan bahwa tiaptiap perikatan dilahirkan baik karena persetujuan, maupun karena Undang-undang. Berdasarkan Pasal 1352 BW, perikatan yang lahir dari undang-undang adalah perikatan yang besumber dari undang-undang saja, dan perikatan yang bersumber dari undang-undang sebagai akibat perbuatan manusia. Perikatan yang lahir dari undang-undang sebagai akibat perbuatan manusia dibagi 2 (dua) yaitu: ${ }^{27}$

1. perikatan yang terbit dari perbuatan yang halal (rechtmatig) diatur dalam Pasal 1357 BW. Figur dari perikatan yang lahir dari undang-undang karena perbuatan manusia yang halal, antara lain perbuatan mewakili orang lain (zaakwaarneming, Pasal 1354 BW), pembayaran hutang yang tidak diwajibkan (onverschuldigde betaling, Pasal 1359 ayat 19 BW),

27 Abdul Hakim Siagian, Hukum Perjanjian, (Medan: UMSU Press, 2014), h. 8-9.

Al-Qānūn, Vol. 20, No. 2, Desember 2017 
perikatan wajar (natuurlijke verbintenis, Pasal 1359 ayat 2 BW).

2. Perbuatan Melanggar Hukum (onrechtmatigedaad) diatur dalam Pasal 1365 BW. Perikatan yang lahir dari undangundang sebagai perbuatan manusia yang melawan hukum ditetapkan bukan saja karena salahnya orang melakukan perbuatan yang bertentangan dengan undang-undang juga karena perbuatan dari orang tersebut bertentangan dengan hukum tidak tertulis (unwritten law).

Dengan perkataan lain, yang dimaksud dengan utang bukan hanya kewajiban untuk membayar sejumlah uang tertentu yang disebabkan karena debitor telah menerima sejumlah uang tertentu karena perjanjian kredit, tetapi juga kewajiban membayar debitor yang timbul dari perjanjianperjanjian lain". ${ }^{28}$ Apabila dilihat dari sumber perikatan maka utang tidak hanya timbul dari perjanjian kredit ataupun perjanjian-perjanjian lain bahkan semakin luas utang dapat timbul dari perbuatan melanggar hukum, baik hukum yang tertulis maupun tidak tertulis. Perbuatan melanggar hukum salah satunya adalah tidak melaksanakan kewajiban hukumnya sebagai mahkluk sosial. Hal tersebut dapat dilihat dari kasus Lindenbaum-Cohen dimana Arrest Hoge Raad pada 31 Januari 1919 memutuskan bahwa pengertian dari Perbuatan Melanggar Hukum menjadi lebih luas. Makna Perbuatan Melanggar Hukum kemudian diartikan tidak hanya perbuatan yang melanggar hukum atau norma-norma yang tertulis saja, melainkan juga meliputi perbuatan yang bertentangan dengan kewajiban hukum si pelaku dan melanggar kaidah hak subjektif orang lain, tetapi juga perbuatan yang melanggar kaidah yang tidak tertulis, yaitu kaidah yang mengatur tata susila, kepatutan, ketelitian dan kehati-hatian yang seharusnya dimiliki seseorang dalam

${ }^{28}$ Rudy A. Lontoh (et.al.), Penyelesaian Utang-piutang melalui Pailit atau Penundaan Pembayaran Utang, (Bandung: Alumni, 2001), h. 117. 
pergaulan hidup dalam masyarakat atau terhadap harta benda warga masyarakat.

Berdasarkan hal tersebut maka apabila seseorang melakukan Perbuatan Melanggar Hukum dan oleh putusan pengadilan yang telah berkekuatan hukum tetap dihukum untuk membayar ganti rugi, biaya dan bunga kepada pihak yang dirugikan, maka saat itu juga seseorang yang melakukan Perbuatan Melanggar Hukum tersebut mempunyai utang kepada pihak yang dirugikan karena saat itu pula timbul kewajiban hukum bagi seseorang yang melakukan Perbuatan Melanggar Hukum tersebut.

Dengan demikian oleh karena kewajiban pembayaran ganti rugi yang diberikan oleh putusan pengadilan atas Perbuatan Melanggar Hukum yang dilakukan oleh si peninggal harta waris merupakan utang dan merupakan bagian dari warisan yang dialihkan kepada ahli waris selain dari hak dan harta kekayan si peninggal harta waris karena warisan menurut $1100 \mathrm{BW}$ adalah semua yang didalamnya juga termasuk utang-utang yang harus dibayar si peninggal harta warisan.

\section{E. Tanggung Gugat Ahli Waris Notaris atas Kerugian Para Pihak}

Warisan meliputi hak dan harta kekayaan milik peninggal harta waris beserta utang yang harus dibayar oleh si peninggal harta warisan. Sebagaimana telah dijelaskan sebelumnya bahwa hukuman pembayaran gantirugi, biaya dan bunga yang dijatuhkan oleh Putusan Pengadilan yang telah berkekuatan hukum tetap kepada si peninggal harta warisan merupakan utang yang melekat pada diri si peninggal harta warisan sehingga apabila si peninggal harta warisan tersebut meninggal dunia maka kewajiban pembayaran gantirugi, biaya dan bunga merupakan bagian dari warisan untuk ahli warisnya. Namun atas warisan tersebut ahli waris dapat menentukan sikap, apakah ahli 
waris menyatakan menerima tanpa syarat, menerima dengan syarat ataupun menolak warisan tersebut

Undang-undang tidak menetapkan suatu waktu, seorang waris harus menentukan sikapnya atas suatu warisan, namun hanya mengatur jangka waktu ahli waris menggunakan hak untuk berpikir (Pasal 1023-1029 BW), yaitu selama 4 bulan terhitung sejak menyampaikan keterangannya kepada Panitera Pengadilan Negeri. Dengan demikian maka terdapat suatu keadaan yang tidak tentu bagi para kreditor dimana hal ketidakpastian tersebut merugikan para kreditor dalam proses penagihan. Oleh karenanya, para kreditor atau pihak yang berkepentingan berhak untuk menggugat para ahli waris agar menyatakan sikapnya. Setelah gugatan diterima oleh ahli waris maka ahli waris dituntut untuk menentukan sikap atas warisannya dan dapat segera memutuskan atau menggunakan hak untuk meminta suatu waktu untuk berpikir (termijn van beraad) melalui Panitera Pengadilan Negeri dengan tenggang waktu selama empat bulan sejak memberikan keterangan di Panitera Pengadilan Negeri.

Selama masa berpikir tersebut ahli waris diwajibkan untuk memelihara harta waris. Akibatnya, selama waktu itu si waris tidak dapat dipaksa untuk melakukan kewajibankewajiban seorang ahli waris. Terhadap dirinya tak dapat dimintakan putusan hakim. Apabila sudah ada sesuatu putusan, pelaksanaannya harus ditangguhkan dahulu. Jika ia digugat sebagai ahli waris, ia dapat mengajukan perlawanan yang bertujuan untuk mempertangguhkan perkara sampai habisnya waktu untuk berfikir. Selama itu ahli waris tersebut, diwajibkan mengurus harta peninggalan itu sebaik-baiknya. la tak boleh menjual apa-apa, sebab perbuatan semacam itu dapat diartikan sebagai penerimaan penuh secara diam-diam (stilzwijgende aanvaarding). ${ }^{29}$

29 Ali Afandi, Hukum Waris, Hukum Keluarga, Hukum Pembuktian, (Jakarta: PT Rineka Cipta, 2000), h. 56.

Al-Qānūn, Vol. 20, No. 2, Desember 2017 
Akibat hukum ahli waris yang menerima warisan penuh atau tanpa syarat berarti harta pribadi bercampur dengan harta warisan, sehingga bila perlu harta pribadinya dapat dikurangi untuk membayar utang-utang si peninggal warisan. $^{30}$ Atas sikap ahli waris tersebut para kreditor ataupun pihak yang berkepentingan tidak kesulitan dalam menuntut kewajiban hukum dari ahli waris karena sikap ahli waris tersebut menunjukkan sikap kesediaan untuk bertanggunggugat atas kewajiban hukum yang sebelumnya melekat pada si peninggal harta waris. Dengan demikian maka apabila ada pihak kreditor ataupun pihak yang berkepentingan menggugat ahli waris almarhum notaris atas kesalahan dalam akta yang dibuat oleh almarhum notaris dan menuntut ganti kerugian, biaya dan bunga maka apabila ahli waris almarhum notaris tersebut menyatakan menerima secara penuh / tanpa syarat baik secara tegas maupun diamdiam maka ahli waris almarhum tersebut secara penuh bertanggung gugat atas kerugian yang diderita oleh pihak yang merasa dirugikan karena akta yang dibuat oleh almarhum notaris. Hakim dapat memutuskan untuk menyita seluruh harta kekayaan milik ahli waris notaris tersebut tidak hanya harta yang diperoleh dari waris melainkan juga sampai pada harta pribadi ahli waris.

Yang kedua, akibat hukum yang ditimbulkan karena sikap ahli waris yang menerima warisan dengan syarat yaitu harta pribadi ahli waris tidak bercampur dengan harta warisan, sehingga hal yang menyangkut dengan utang-utang si peninggal warisan hanya dibayar sampai nilai harta warisan. ${ }^{31}$ Dengan demikian maka ahli waris baru dapat menerima harta warisan apabila masih ada sisa dari harta peninggalan yang terlebih dahulu dipergunakan untuk melunasi utang si peninggal harta waris kepada para kreditor.

${ }^{30}$ Henny Tanuwidjaja, Hukum Waris Menurut BW, h. 63

31 Ibid., h. 64.

Al-Qānūn, Vol. 20, No. 2, Desember 2017 
Atas sikap ini ahli waris beneficiary aanvarding dibebani kewajiban diantaranya : ${ }^{32}$

1. Melakukan pencatatan adanya harta peninggalan dalam waktu empat bulan setelahnya ia menyatakan kehendaknya kepada Panitera Pengadilan Negeri, bahwa ia menerima warisannya secara beneficiair.

2. Mengurus harta peninggalan sebaik-baiknya.

3. Selekas-lekasnya membereskan urusan warisan ( $d e^{\prime}$ boedel tot effenheid brengen").

4. Apabila diminta oleh semua orang berpiutang harus memberikan tanggungan untuk harga benda-benda yang bergerak beserta benda-benda yang tak bergerak yang tidak diserahkan kepada orang-orang berpiutang yang memegang hypotheek.

5. Memberikan pertanggunganjawab kepada sekalian penagih hutang dan orang-orang yang menerima pemberian secara legaat. Pekerjaan ini berupa menghitung harga serta pendapatan-pendapatan yang mungkin akan diperoleh, jika barang-barang warisan dijual dan sampai berapa persen piutang-piutang dan legaten itu dapat dipenuhi.

6. Memanggil orang-orang berpiutang yang tidak terkenal, dalam surat kabar resmi. Sebenarnya, peraturan yang diberikan oleh undang-undang mengenai pemberesan harta peninggalan dalam hal penerimaan warisan secara beneficiair ini, adalah sangat sederhana dan kurang jelas.

Atas hal tersebut maka apabila ahli waris beneficiair mendapat gugatan dari para kreditor dari si peninggal waris maka ahli waris tersebut mempunyai kewajiban mengurus harta warisan dan baru menerima harta warisan apabila terdapat sisa dari pembayaran utang-utang si peninggal waris. Bagi kreditor apabila sudah lampau 3 bulan sejak harta warisan diterima ahli waris dan 6 bulan setelah meninggalnya si peninggal warisan maka apabila kreditor dapat membuktikan suatu warisan tidak akan mencukupi

32 Subekti, Pokok-pokok Hukum Perdata, h. 104.

Al-Qānūn, Vol. 20, No. 2, Desember 2017 
untuk melunasi hutang-hutang si meninggal, maka biasanya ditempuh jalan meminta pada hakim supaya warisan itu dinyatakan pailit. Dengan demikian maka apabila ahli waris almarhum notaris atas gugatan Perbuatan Melanggar Hukum yang diajukan oleh pihak yang dirugikan atas akta almarhum notaris maka ahli waris notaris yang menerima warisan secara beneficiary tidak dapat bertanggunggugat sampai dengan harta pribadinya.

Yang ketiga, apabila ahli waris menolak harta warisan, maka berdasarkan pasal 1061 BW, pihak kreditor dapat meminta kepada hakim agar ia diberi kuasa untuk mengganti menerima harta warisan atas nama ahli waris yang menolak warisan. ${ }^{33}$ Berdasarkan hal tersebut maka apabila terdapat gugatan terhadap ahli waris almarhum notaris dari pihak yang dirugikan akibat akta yang dibuat oleh almarhum notaris maka apabila ahli waris almarhum notaris menyatakan menolak waris maka upaya yang dapat dilakukan oleh pihak yang dirugikan tersebut adalah permohonan untuk menerima harta warisan atas nama ahli waris yang menolak warisan tersebut sebagai upaya untuk mendapatkan haknya.

\section{F. Penutup}

Jabatan Notaris merupakan pendukung hak dan kewajiban dan oleh pemerintah diberikan kekuasaan untuk membuat akta otentik. Namun apabila terjadi kesalahan terhadap akta otentik yang dibuat oleh Notaris, merupakan suatu kesalahan karena Jabatan yang diembannya dan pertanggungjawaban Notaris bergantung pada kesalahan yang diperbuatnya. Apabila terdapat kesalahan minor maka notaris melakukan pembetulan. Selanjutnya apabila akta tersebut turun kekuatan hukumnya menjadi akta bawah tangan, atau bahkan oleh pengadilan dinyatakan batal ataupun batal demi hukum, maka notaris bertanggunggugat

${ }^{33}$ Ibid., h. 65.

Al-Qānūn, Vol. 20, No. 2, Desember 2017 
atas kerugian yang diderita oleh pihak yang dirugikan baik secara materiil maupun immaterial.

Selanjutnya, apabila notaris tersebut meninggal dunia maka para pihak yang dirugikan tersebut oleh hukum diperbolehkan untuk menggugat ahli waris almarhum notaris dengan dasar kewajiban pembayaran ganti rugi, biaya dan bunga dari putusan pengadilan yang berkekuatan hukum tetap atas Perbuatan Melanggar Hukum yang dilakukan oleh almarhum notaris yang merupakan utang almarhum notaris. Dikarenakan warisan tidak hanya meliputi hak dan harta kekayaan saja melainkan juga meliputi utang sehingga hukuman pembayaran ganti rugi, bunga dan biaya atas Perbuatan Melanggar Hukum almarhum notaris dapat beralih ke ahli waris almarhum notaris sebagai warisan. Namun oleh hukum pula ahli waris tersebut diberikan hak untuk memilih menerima warisan, menerima warisan dengan syarat atau menolak warisan.

\section{Daftar Pustaka}

Sjaifurrachman dan Habib Adjie. Aspek Pertanggungjawaban Notaris dalam Pembuatanb Akta. Bandung: Mandar Maju, 2011.

Teguh Samudera. Hukum Pembuktian dalam Acara Perdata. Bandung: Alumni, 1992.

Marthalena Pohan. Tanggunggugat Advocaat, Dokter, Notaris. Surabaya: Bina Ilmu, 1985.

Departemen Pendidikan Nasional. Kamus Besar Bahasa Indonesia Pusat Bahasa (Edisi Keempat). Jakarta: Gramedia Pustaka Utama, 2008.

J.H. Nieuwenhuis. Hoofdstukken Verbintenissenrecht. Terj. Surabaya: Universitas Airlangga, 1985.

M. Idris Ramulyo. Perbandingan Hukum Kewarisan Islam dengan Kewarisan Kitab Undang-undang Hukum Perdata. Jakarta: Sinar Grafika, 2004. 
A. Wahab Afif. Fiqh Mewaris. Semarang: Yayasan Ulumul Quran, 1994.

Suparman Usman. Ikhtisar Hukum Waris Menurut Kitab Undang-undang Hukum Perdata (Burgerlijk Wetboek). Serang: Darul Ulum Press. 1993.

Surini Ahlan Sjarif dan Nurul Elmiyah. Hukum Kewarisan Perdata Barat. Jakarta: Fakultas Hukum Universitas Indonesia, 2005.

Abdulkadir Muhammad. Hukum Perdata Indonesia. Bandung: Citra Aditya Bakti, 2000.

Henny Tanuwidjaja. Hukum Waris Menurut BW. Bandung: Refika Aditama, 2012.

Ridwan Setiawan dalam Oemar Moecthar. "Kedudukan Negara sebagai Pengelola Warisan atas Harta Peninggalan Tak Terurus dalam Sistem Hukum Waris Burgerlijk Wetboek". Yuridika, Vol. 32, 2 Mei 2017.

Hartono Soerjopratiknyo. Hukum Waris Tanpa Wasiat. Yogyakarta: Andi Offset, 1983.

Ter Haar Bzn. Asas-asas dan Susunan Hukum Adat, Terj. K. Ng. Soebakti Poesponoto. Jakarta: Pradnya Paramita, 1981.

Sri Soedewi Masjchoen Sofwan. Hukum Perdata (Hukum Perutangan): Bagian A. Yogyakarta: Seksi Hukum Perdata UGM, 1980.

Yahya Harahap. Segi-segi Hukum Perjanjian. Bandung: Alumni, 1986.

Subekti. Pokok-pokok Hukum Perdata. Jakarta: PT. Intermasa, 1985.

Abdul Hakim Siagian. Hukum Perjanjian. Medan: UMSU Press, 2014.

Rudy A. Lontoh (et.al.). Penyelesaian Utang-piutang melalui Pailit atau Penundaan Pembayaran Utang. Bandung: Alumni, 2001.

Ali Afandi. Hukum Waris, Hukum Keluarga, Hukum Pembuktian. Jakarta: PT Rineka Cipta, 2000.

Eman Suparman. Hukum Waris di Indonesia dalam Perspektif Islam, Adat, dan BW. Bandung: Refika Aditama, 2005. 